\title{
Pengaruh Profitabilitas, Kebijakan Hutang Dan Pertumbuhan Perusahaan Terhadap Kebijakan Dividen (Pada Perusahaan Sektor Industri Dasar Dan Kimia Tahun 2017-2019)
}

\author{
Miken Gusnawati Dewi ${ }^{1}$, Mohamad Zulman Hakim ${ }^{2}$, Dirvi Surya \\ Abbas $^{3}$ \\ Universitas Muhammadiyah Tangerang ${ }^{1,2,3}$ \\ email korespondensi: mikendewi@gmail.com
}

\begin{abstract}
Abstrak: Kebijakan dividen merupakan keputusan apakah laba yang diperoleh perusahaan akan dibagikan kepada pemegang saham sebagai dividen atau akan ditahan dalam bentuk laba ditahan guna pembiayaan investasi dimasa yang akan datang. Penelitian ini bertujuan untuk menganalisis pengaruh Profitabilitas, Kebijakan Hutang dan Pertumbuhan Perusahaan terhadap Kebijakan Dividen. Jenis penelitian yang digunakan adalah penelitian kuntitatif. Populasi dalam penelitian ini adalah Perusahaan Manufaktur yang terdaftar di Bursa Efek Indonesia pada tahun 2017-2019. Sampel ditentukan menggunakan metode purposive sampling sehingga diperoleh 36 sampel dengan jumlah 12 perusahaan. Penelitian ini menggunakan metode analisis statistik deskriptif, analisi regresi data panel dan uji hipotesis dengan menggunakan program Eviews 9. Berdasarkan hasil penelitian menunjukkan bahwa secara parsial profitabilitas berpengaruh terhadap kebijakan dividen sedangkan kebijakan hutang dan pertumbuhan perusahaan tidak berpengaruh terhadap kebijakan dividen.
\end{abstract}

Kata kunci: Profitabilitas, Kebijakan Hutang, Pertumbuhan Perusahaan, Kebijakan Dividen

Teori keagenan menjelaskan bahwa kepentingan manajemen dan kepentingan pemegang saham sering kali bertentangan sehingga dapat terjadi konflik di antaranya (Tarjo dan Hartono, 2003). Hal tersebut sering terjadi karena manager cenderung berusaha mengutamakan kepentingan pribadi. Sedangkan pemegang saham tidak menyukai kepentingan pribadi manager karena hal tersebut akan menambah kos bagi perusahaan dan akan menurunkan keuntungan yang akan diterima oleh pemegang saham. Akibat dari perbedaan itulah maka terjadi konflik yang bisa disebut agency conflict.

Fenomena yang terjadi pada perusahaan PT Holcim Indonesia Tbk pada tahun 2017 memutuskan untuk tidak membagikan dividen kepada para pemegang saham karena penjualan yang mengalami penurunan hingga $12 \%$ sehingga perusahaan tidak memiliki kas yang cukup untuk membayarkan dividen.

Hal berbeda terjadi pada perusahaan PT Semen Baturaja Tbk (SMBR) pada tahun 2017 membagikan dividen sebesar Rp 64,77 miliar kepada seluruh pemegang sahamnya. Besaran dividen tunai tersebut setara 25\% dari perolehan laba perusahaan di sepanjang tahun 2016 yang mencapai $\mathrm{Rp} 259,09$ miliar. Sisa perolehan laba bersih perusahaan pada tahun 2015 akan dibukukan sebagai dana cadangan atau laba ditahan guna mendukung bisnis perusahaan (www.sindonews.com). 
Berdasarkan hasil penelitian yang dilakukan Komang dan Luh (2015) menyatakan bahwa profitabilitas tidak berpengaruh terhadap kebijakan dividen. Namun hasil penelitian berbeda dengan yang dilakukan oleh Aimee dan Lailatul (2017) bahwa profitabilitas berpengaruh signifikan terhadap kebijakan dividen. Kebijakan hutang menurut penelitian yang dilakukan oleh Resky, Parengkuan dan Ivonne (2014) berpengaruh negatif terhadap kebijakan dividen. Sedangkan menurut Ayu dan Andayani (2017) menyatakan bahwa kebijakan hutang tidak berpengaruh terhadap kebijakan dividen. Hal ini berbeda dengan penelitian yang dilakukan oleh Seleman dan Rina (2018) yang menunjukkan bahwa kebijakan hutang berpengaruh positif terhadap kebijakan dividen. Menurut Komang dan Luh (2015) menyatakan bahwa pertumbuhan perusahaan berpengaruh negatif terhadap kebijakan dividen. Namun bertentangan dengan hasil penelitian yang dilakukan oleh Aimee dan Lailatul (2017) yang menyatakan bahwa pertumbuhan perusahaan berpengaruh positif terhadap kebijan dividen.

\section{METODE}

Penelitian ini menggunakan pendekatan kuantitatif dengan menggunakan data sekunder, yaitu data yang diperoleh dari Bursa Efek Indonesia (BEI).

Penelitian ini merupakan penelitian yang berbentuk asosiatif , yaitu penelitian yang mencari pengaruh suatu variabel bebas terhadap variabel terkait (Sugiyono, 2008). Populasi penelitian ini adalah perusahaan manufaktur sektor industri dasar dan kimia yang tercatat di Bursa Efek Indonesia dari tahun 2017 sampai 2019. Penelitian ini menggunakan metode purposive sampling dalam pengambilan sampel. Prosedur penentuan sampel menggunakan metode purposive sampling yaitu teknik penentuan sampel berdasarkan pertimbangan atau kriteria tertentu (Sugiyono, 2018). Adapun kriteria-kriteria yang telah ditetapkan sebagai berikut :

a. Perusahaan sektor industri dasar dan kimia yang terdaftar di Bursa Efek Indonesia periode 2017-2019.

b. Perusahaan sektor industri dasar dan kimia menerbitkan laporan keuangan lengkap selama 2017-2019.

c. Perusahaan sektor industri dasar dan kimia yang mengalami laba selama 2017-2019.

d. Perusahaan sektor industri dasar dan kimia yang menerbitkan laporan keuangan dalam mata rupiah selama 2017-2019.

e. Perusahaan sektor industri dasar dan kimia yang membagikan dividen selama 2017-2019.

Dalam penelitian ini menggunakan analisis regresi data panel dengan software pengolah data Eviews 9.0. Berikut adalah metode analisis data yang digunakan :

1. Analisis Statistik Deskriptif

Statistik Deskriptif memberikan gambaran umum terhadap objek penelitian yang dijadikan sampel penelitian. Statistik deskriptif 
menunjukkan nilai Mean, Median, Maximum, Minimum, Standard Deviation, Skewness, Kurtosis dan Jarque-Bera.

2. Estimasi Model Regresi Data Panel

a. Common Effect Model (CEM)

Common Effects Model (CEM) merupakan model yang paling sederhana dibandingkan dengan Fixed Effect Model (FEM) ataupun Random Effects Model (REM) dalam regresi data panel.

Asumsi pertama yang dikenal dalam regresi data panel dengan model common effects adalah asumsi yang menganggap bahwa intersep dan slope selalu tetap baik antar waktu maupun antar individu. Setiap individu (n) yang diregresi untuk mengetahui hubungan antara variabel dependen dengan variabel-variabel independen akan memberikan intersep maupun slope yang sama besarnya. Begitupula dengan waktu (t), nilai intersep dan slope dalam persamaan regresi data panel model common effects menggambarkan hubungan antara variabel dependen dengan variabel-variabel independen adalah sama untuk setiap waktu, hal ini dikarenakan dasar yang digunakan dalam regresi data panel model common effects yang mengabaikan pengaruh individu dan waktu pada model yang dibentuknya (Sriyana, 2014:107).

b. Fixed Effect Model (FEM)

Model efek tetap (fixed effects) adalah model regresi data panel yang dapat menunjukkan adanya perbedaan konstanta antar obyek dalam koefisien regresi yang sama. Fixed effect menggambarkan suatu obyek observasi memiliki konstanta yang bernilai tetap untuk beberapa periode waktu. Demikian pula dengan koefisien regresinya memiliki nilai yang tetap untuk beberapa periode waktu (time invariant) (Sriyana, 2014:121).

c. Random Effect Model (REM)

Pada model random effects diasumsikan bahwa perbedaan intersep dan konstanta disebabkan oleh residual / eror sebagai akibat perbedaan antar sampel dan periode waktu yang terjadi secara random. Untuk menganalisis dengan metode random effects ada satu syarat yang harus terpenuhi yaitu obyek data cross section harus lebih besar daripada banyaknya koefisien. Artinya untuk melakukan analisis sebanyak 3 variabel (baik independen maupun dependen) maka minimal harus ada 3 data cross section. Hal ini berkaitan dengan derajat kebebasan data yang akan dianalisis. Jika syarat ini dilanggar, maka koefisien efek random tidak dapat diestimasi atau akan menghasilkan angka nol (Sriyana, 2014:154).

3. Teknik Pemilihan Model Regresi Data Panel

1. Uji Chow

Uji Chow digunakan untuk memilih model yang digunakan apakah sebaiknya menggunakan common effect atau fixed effect. Pengujian 
ini dapat dilihat pada nilai Probabilitas (Prob.) Cross-section $\mathrm{F}$ dan Cross-section Chi-Square dengan hipotesis sebagai berikut :

$\mathrm{H}_{0}$ : Model mengikuti common effect model jika Probabilitas Crosssection $\mathrm{F}$ dan Cross-section chi-square $>\alpha(0,05)$

$\mathrm{Ha}$ : Model mengikuti fixed effect model jika Probabilitas Cross-section

$\mathrm{F}$ dan Cross-section chi-square $<\alpha(0,05)$

2. Uji Hausman

Uji Hausman digunakan untuk memilih model yang digunakan apakah sebaiknya menggunakan random effect atau fixed effect. Pengujian ini dapat dilihat pada nilai Probabilitas (Prob.) Cross-section random dengan hipotesis sebagai berikut :

$\mathrm{H}_{0}$ : Model mengikuti random effect model jika nilai Probabilitas crosssection random $>\alpha(0,05)$

$\mathrm{Ha}$ : Model mengikuti fixed effect model jika nilai Probabilitas Crosssection random $<\alpha(0,05)$

3. Uji Lagrange Multiplier

Uji Lagrange Multiplier digunakan untuk memilih model yang digunakan apakah sebaiknya menggunakan random effect atau common effect. Pengujian ini dapat dilihat pada nilai Probibalitas Breush-pagan dengan hipotesis sebagai berikut :

$\mathrm{H}_{0}$ : Model mengikuti common effect model jika nilai Probabilitas Cross-section Breush-pagan $>\alpha(0,05)$

$\mathrm{Ha}$ : Model mengikuti random effect model jika nilai Probabilitas Cross-section Breush-pagan $<\alpha(0,05)$

4. Uji Hipotesis

a. Uji Kelayakan Model (Uji F)

Uji $F$ digunakan untuk menunjukkan apakah variabel independe secara bersama-sama mempunyai pengaruh terhadap variabel dependen dengan hipotesis sebagai berikut :

Berdasarkan perbandingan antara F-statistik dengan $F$ tabel

$\mathrm{H}_{0}$ : nilai F-statistik < $\mathrm{F}$ tabel

$\mathrm{Ha}$ : nilai F-statistik > F tabel

Berdasarkan probabilitas

$\mathrm{H}_{0}$ : Nilai Prob (F-Statitik) $>\alpha(0,05)$

$\mathrm{Ha}$ : Nilai Prob (F-statistik) $<\alpha(0,05)$

b. Uji $R^{2}$ (Koefisien Determinasi)

Uji $R^{2}$ digunakan untuk memprediksi seberapa besar kontribusi pengaruh variabel independen terhadap variabel dependen. Nilai Rsquared berada antara 0 sampai 1 dengan penjelasan sebagai berikut :

> Nilai R-squared harus berkisar 0 sampai 1.

$>$ Jika nilai R-squared sama dengan 1, berarti naik atau turunnya variabel dependen $100 \%$ dipengaruhi oleh variabel independen.

$>$ Jika nilai R-squared sama dengan 0, berarti tidak ada hubungan sama sekali antara variabel independen terhadap variabel dependen. 
c. Uji t

Uji t digunakan untuk mengetahui signifikan tidaknya pengaruh dari variabel independen terhadap variabel dependen dengan hipotesis sebagai berikut :

Berdasarkan perbandingan antara t statistik dengan t tabel

$\mathrm{H}_{0}$ : nilai t-statistik < t tabel

$\mathrm{Ha}$ : nilai T-statistik > t tabel

Berdasarkan probability

$\mathrm{H}_{0}$ : nilai Prob. $>\alpha(0,05)$

$\mathrm{Ha}:$ nilai Prob. $<\alpha(0,05)$

5. Analisis Regresi Data Panel

Analisis ini digunakan untuk mengetahui arah hubungan antara variabel independen dengan variabel dependen dengan persamaan sebagai berikut :

$$
\mathrm{DPR}=a+\beta_{1} \mathrm{ROA}+\beta_{2} \mathrm{DAR}+\beta_{3} \mathrm{GROWT}+\mathrm{e}
$$

Keterangan :

DPR

$\alpha$

$\beta$

ROA

DAR

GROWTH

e
: Kebijakan Dividen

: Konstanta

: Koefisien Regresi

: Profitabilitas

: Kebijakan Hutang

:Pertumbuhan Perusahaan

: Error

\section{HASIL}

Tabel 1. Analisis Statistik Deskriptif

Date: 01/12/21 Time: 11:00

Sample: 20172019

\begin{tabular}{lcccc}
\hline \hline & DPR & ROA & DAR & GROWTH \\
\hline \hline Mean & 0.588528 & 0.062433 & 0.402836 & 0.088331 \\
Median & 0.461800 & 0.057550 & 0.429000 & 0.064400 \\
Maximum & 2.248700 & 0.141100 & 0.783000 & 1.614900 \\
Minimum & 0.053700 & 0.012000 & 0.090400 & -0.998400 \\
Std. Dev. & 0.497973 & 0.030166 & 0.219724 & 0.334596 \\
Skewness & 1.742072 & 0.789294 & -0.001248 & 1.805213 \\
Kurtosis & 5.898895 & 3.130966 & 1.686559 & 16.09449 \\
& & & & \\
Jarque-Bera & 30.81427 & 3.763636 & 2.587699 & 276.7512 \\
Probability & 0.000000 & 0.152313 & 0.274213 & 0.000000 \\
& & & & \\
Sum & 21.18700 & 2.247600 & 14.50210 & 3.179900 \\
Sum Sq. Dev. & 8.679189 & 0.031850 & 1.689758 & 3.918411 \\
& & & & \\
Observations & 36 & 36 & 36 & 36
\end{tabular}

Nilai Mean terbesar dialami oleh variabel DPR yaitu sebesar 0,588528 sementara variabel ROA memiliki nilai Mean terkecil yaitu sebesar 0,062433 . 
Nilai Median terbesar dialami oleh variabel DPR yaitu sebesar 0,461800 sementara variabel ROA memiliki nilai Median terkecil yaitu 0,057550.

Nilai Maximum terbesar dialami oleh variabel DPR yaitu sebesar 2,248700 sementara variabel ROA memiliki nilai Maximum terkecil yaitu 0,141100.

Nilai Minimum terbesar dialami oleh variabel DAR yaitu sebesar 0,090400 sementara variabel GROWTH memiliki nilai Minimum terkecil yaitu 0,998400 .

Nilai Standar Deviasi terbesar dialami oleh variabel DPR yaitu sebesar 0,497973 yang berarti bahwa variabel DER memiliki tingkat risiko yang lebih tinggi mengalami perubahan dibandingkan dengan variabel- variabel yang lain selama periode penelitian. Sementara variabel ROA mempunyai tingkat risiko yang paling rendah, yaitu sebesar 0,030166. Hal ini menunjukkan bahwa variabel ROA selama periode penelitian mengalami perubahan yang tidak terlalu fluktuatif.

Nilai Skewness yang memiliki nilai di atas 0 (nol) yaitu variabel DPR dan GROWTH yang berarti bahwa ketinggian distribusi data tidak normal, sedangkan variable ROA dan DAR memiliki nilai di sekitaran 0 (nol) yang berarti bahwa asimetri distribusi data disekitar mean bersifat normal.

Nilai Kurtosis untuk variabel DPR, ROA dan GROWTH memiliki nilai Kurtosis lebih dari 3 yang berarti bahwa ketinggian distribusi data tidak normal, sementara variabel DAR memiliki nilai Kurtosis kurang dari 3 yang berarti bahwa ketinggian distribusi data bersifat normal.

Jarque-Bera adalah uji statistik untuk mengetahui apakah data berdistribusi normal. Uji ini mengukur perbedaan skewness dan kurtosis data dan dibandingkan dengan apabila datanya bersifat normal. Dengan $\mathrm{H}_{0}$ pada data berdistribusi normal, uji Jarque-Bera didistribusi dengan $\mathrm{X}^{2}$ dengan derajat bebas (degree of freedom) sebesar 2.

Probability menunjukkan kemungkinan nilai Jarque-Bera melebihi (dalam nilai absolut) nilai terobservasi di bawah hipotesis nol. Nilai probabilitas yang kecil cenderung mengarahkan pada penolakan hipotesis nol distribusi normal. Nilai probabilitas variabel ROA sebesar 0,152313 dan DAR sebesar 0,274213 (lebih besar dari $\alpha=5 \%$ ), kita dapat menolak $\mathrm{H}_{0}$ bahwa data berdistribusi normal.

Ređundant Fixed Effects Tests

Tabel 2. Uji Chow

Equation: EQ01

Test cross-section fixed effects

\begin{tabular}{lrrr}
\hline \hline Effects Test & Statistic & d.f. & Prob. \\
\hline \hline Cross-section F & 3.903653 & $(11,21)$ & 0.0036 \\
Cross-section Chi-square & 40.083317 & 11 & 0.0000 \\
\hline \hline
\end{tabular}

Berdasarkan hasil perhitungan di atas, nilai Probabilitas Crosssection $F$ dan Cross-section Chi-square $<\alpha(0,05)$, Maka dapat 
disimpulkan bahwa Fixed Effect Model (FEM) lebih layak digunakan dibandingkan Common Effect Model (CEM).

\section{Tabel 3. Uji Hausman}

Correlated Random Effects - Hausman Test

Equation: EQ01

Test cross-section random effects

\begin{tabular}{lrrr}
\hline \hline Test Summary & Chi-Sq. Statistic & Chi-Sq.d.f. & Prob. \\
\hline \hline Cross-section random & 0.622890 & 3 & 0.8912 \\
\hline \hline
\end{tabular}

Berdasarkan hasil perhitungan diatas nilai Probabilitas (Prob.) Cross-section random $>\alpha(0,05)$, maka dapat disimpulkan bahwa Random Effect Model (REM) lebih layak digunakan dibandingkan Fixed Effect Model (FEM).

\section{Tabel 4. Uji Lagrange Multiplier}

Lagrange Multiplier Tests for Random Effects

Null hypotheses: No effects

Alternative hypotheses: Two-sided (Breusch-Pagan) and one-sided (all others) alternatives

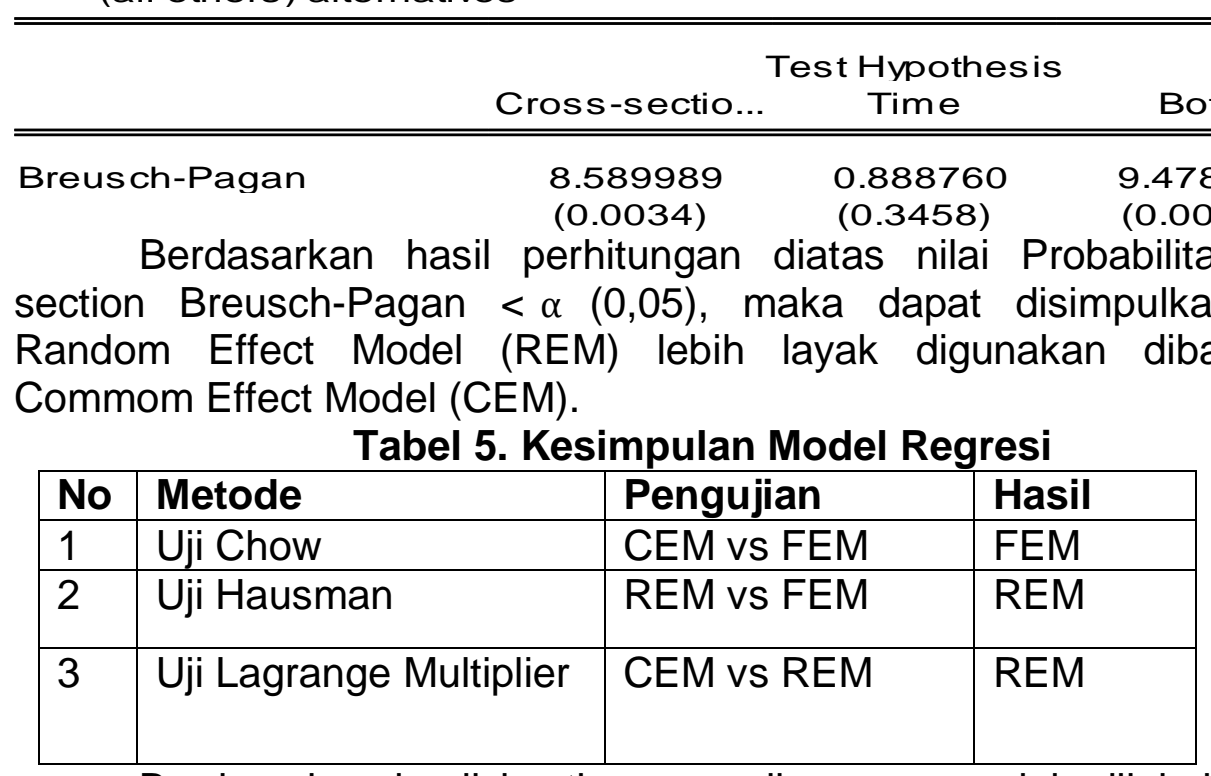

Berdasarkan hasil ke tiga pengujian yang sudah dilakukan maka dapat disimpulkan bahwa Model Regresi Data Panel yang akan digunakan dalam uji hipotesis dan persamaan Regresi Data Panel adalah model Random Effect Model (REM). 


\section{Tabel 6. Random Effect Model (REM)}

Dependent Variable: DPR

Method: Panel EGLS (Cross-section random effects)

Date: 01/12/21 Time: 11:28

Sample: 20172019

Periods included: 3

Cross-sections included: 12

Total panel (balanced) observations: 36

Swamy and Arora estimator of component variances

\begin{tabular}{|c|c|c|c|c|}
\hline Variable & Coefficient & Std. Error & $\mathrm{t}$-Statistic & Prob. \\
\hline C & 1.524403 & 0.343114 & 4.442844 & 0.0001 \\
\hline ROA & -9.438949 & 2.923792 & -3.228324 & 0.0029 \\
\hline DAR & -0.863307 & 0.550552 & -1.568077 & 0.1267 \\
\hline GROWTH & 0.013594 & 0.190606 & 0.071321 & 0.9436 \\
\hline \multicolumn{5}{|c|}{ Effects Specification } \\
\hline & & & S.D. & Rho \\
\hline Cross-section random & & & 0.365179 & 0.5779 \\
\hline Idiosyncratic random & & & 0.312108 & 0.4221 \\
\hline \multicolumn{5}{|c|}{ Weighted Statistics } \\
\hline R-squared & 0.272749 & \multirow{5}{*}{\multicolumn{2}{|c|}{$\begin{array}{l}\text { Mean dependent var } \\
\text { S.D. dependent var } \\
\text { Sum squared resid } \\
\text { Durbin-Watson stat }\end{array}$}} & 0.260426 \\
\hline Adjusted R-squared & 0.204570 & & & 0.336699 \\
\hline S.E. of regression & 0.300292 & & & 2.885603 \\
\hline F-statistic & 4.000445 & & & 1.643144 \\
\hline Prob(F-statistic) & 0.015854 & & & \\
\hline \multicolumn{5}{|c|}{ Unweighted Statistics } \\
\hline R-squared & 0.274525 & \multirow{2}{*}{\multicolumn{2}{|c|}{$\begin{array}{l}\text { Mean dependent var } \\
\text { Durbin-Watson stat }\end{array}$}} & 0.588528 \\
\hline Sum squared resid & 6.296531 & & & 0.753027 \\
\hline
\end{tabular}

Pada output di atas menunjukkan bahwa nilai F-statistic sebesar 4,000445 sementara F Tabel dengan tingkat $\alpha 5 \%$, df1 $(\mathrm{k}-1)=3$ dan df2 $(n-k)=32$ didapat nilai $F$ Tabel sebesar 2,90. Dengan demikian F-statistic $(4,000445)>$ F Tabel $(2,90)$ dan nilai Prob (F-statistic) 0,015854 < 0,05. Maka dapat disimpulkan bahwa Ha diterima, maka dengan demikian dapat disimpulkan bahwa variabel-variabel independen dalam penelitian ini yang terdiri dari ROA, DAR dan GROWTH secara bersama-sama memiliki pengaruh terhadap DPR.

Pada output di atas menunjukkan bahwa nilai Adjusted R-Squared sebesar 0,204570 artinya bahwa variasi perubahan naik turunnya DPR dapat dijelaskan oleh ROA, DAR dan GROWTH sebesar 20,45\% sementara sisanya yaitu $79,55 \%$ dijelaskan oleh variabel-variabel lain yang tidak diteliti dalam penelitian ini.

- Nilai $t$-statistik ROA sebesar -3,228324, sementara t Tabel dengan tingkat $\alpha 5 \%$, df1 $(\mathrm{k}-1)=3$ dan df2 $(\mathrm{n}-\mathrm{k})=32$ didapat nilai $\mathrm{t}$ Tabel sebesar 2,03693. Dengan demikian t-statistik ROA $(-3,228324)>t$ Tabel (2,03693) dan nilai Prob. 0,0029 < 0,05. Maka dapat disimpulkan bahwa variabel ROA dalam penelitian ini memiliki pengaruh terhadap DPR.

- Nilai $t$-statistik DAR sebesar $-1,568077$, sementara t Tabel dengan tingkat $\alpha 5 \%$, df1 $(\mathrm{k}-1)=3$ dan df2 $(n-k)=32$ didapat nilai t Tabel 
sebesar 2,03693. Dengan demikian t-statistik DAR $(-1,568077)<\mathrm{t}$ Tabel (2,03693) dan nilai Prob. 0,1267>0,05. Maka dapat disimpulkan bahwa variable DAR dalam penelitian ini tidak memiliki pengaruh terhadap DPR.

- Nilai $t$-statistik GROWTH sebesar 0,071321, sementara t Tabel dengan tingkat $\alpha 5 \%$, df1 $(\mathrm{k}-1)=3$ dan df2 $(\mathrm{n}-\mathrm{k})=32$ didapat nilai $\mathrm{t}$ Tabel sebesar 2,03693. Dengan demikian t-statistik GROWTH $(0,071321)<\mathrm{t}$ Tabel $(2,03693)$ dan nilai Prob. 0,9436 > 0,05. Maka dapat disimpulkan bahwa variabel GROWTH dalam penelitian ini tidak memiliki pengaruh terhadap DPR.

\section{PEMBAHASAN}

Berdasarkan hasil Random Effect Model (REM) dapat diketahui bahwa persamaan regresi data panel adalah sebagai berikut :

$\mathrm{DPR}=1,524403-9,438949-0,863307+0,013594+\mathrm{e}$

Makna :

a. Nilai Konstanta sebesar 1,524403 menunjukkan bahwa jika variable independent tidak ada atau bernilai 0 maka nilai kebijakan dividen sebesar 1,524403.

b. Nilai koefisien Regresi Profitabilitas sebesar $-9,438949$ menunjukkan bahwa setiap kenaikan profitabilitas sebesar $1 \%$ akan menyebabkan kenaikan kebijakan dividen sebesar 9,438949 .

c. Nilai koefisien Regresi Kebijakan hutang sebesar -0,863307 menunjukkan bahwa setiap kenaikan kebijakan hutang sebesar $1 \%$ akan menyebabkan kenaikan kebijakan dividen sebesar 0,863307 .

d. Nilai koefisien Regresi Pertumbuhan Perusahaan sebesar 0,013594 menunjukkan bahwa setiap kenaikan pertumbuhan perusahaan sebesar $1 \%$ akan menyebabkan kenaikan kebijakan dividen sebesar 0,013594

\section{Interpretasi hasil}

Profitabilitas dengan nilai koefisien -9,438949 dan nilai Prob 0,0029 $<\alpha$ menunjukkan bahwa $\mathrm{H}_{1}$ diterima, maka kesimpulannya adalah profitabilitas berpengaruh dan signifikan terhadap kebijakan dividen. Hasil penelitian ini sesuai dengan penelitian yang dilakukan oleh Aimee dan Lailatul (2017) yang menyatakan bahwa profitabilitas berpengaruh signifikan terhadap kebijakan dividen.

Kebijakan Hutang dengan nilai koefisien -0,863307 dan nilai Prob $0,1267>\alpha$ menunjukkan bahwa $\mathrm{H}_{2}$ ditolak, maka kesimpulannya adalah kebijakan hutang tidak berpengaruh terhadap kebijakan dividen. Hasil penelitian ini sesuai dengan penelitian yang dilakukan Ayu dan Andayani (2017) menyatakan bahwa kebijakan hutang tidak berpengaruh terhadap kebijakan dividen. 
Pertumbuhan Perusahaan dengan nilai koefisien 0,013594 dan nilai Prob 0,9436> $>$ menunjukkan bahwa $\mathrm{H}_{3}$ ditolak, maka kesimpulannya adalah pertumbuhan perusahaan tidak berpengaruh terhadap kebijakan dividen.

\section{KESIMPULAN \\ Kesimpulan}

Berdasarkan hasil penelitian, maka dapat ditarik kesimpulan sebagai berikut :

1. Secara simultan (Uji F) variabel Profitabilitas, Kebijakan Hutang dan Pertumbuhan Perusahaan secara bersama-sama memiliki pengaruh terhadap Kebijakan Dividen.

2. Secara parsial (Uji t) variabel Profitabilitas berpengaruh terhadap kebijakn dividen sedangkan Kebijakan Hutang dan Pertumbuhan Keterbatasan Perusahaan tidak berpengaruh terhadap Kebijakan Dividen.

Keterbatasan penelitian yang dilakukan dalam penelitian ini diantaranya, peneliti hanya mengambil data perusahaan yang tidak mengalami kerugian.

\section{Saran}

Berdasarkan hasil penelitian, terdapat beberapa saran untuk perbaikan penelitian selanjutnya sebagai berikut :

1. Bagi pihak manajemen perusahaan sangat diharapkan agar lebih memperhatikan pembagian dividen kepada para pemegang saham. Hal ini bertujuan untuk bisa menarik investor berinvestasi pada perusahaan Ketika perusahaan mengalami kesulitan dana.

2. Untuk penelitian selanjutnya, penelitian ini dapat dikembangkan dengan menambahkan variabel lain yang dapat digunakan untuk mengukur kebijakan dividen yang dilakukan oleh perusahaan serta dapat menambahkan periode waktu penelitian.

\section{DAFTAR PUSTAKA}

Eksandy, A. (2018). METODE PENELITIAN AKUNTANSI DAN MANAJEMEN (M.Z. Hakim (ed.)). FEB UMT.

Ayu Novita Sari, K., \& Komang Sudjarni, L. (2015). Pengaruh Likuiditas, Leverage, Pertumbuhan Perusahaan, Dan Profitabilitas Terhadap Kebijakan Dividen Pada Perusahaan Manufaktur Di Bei. E-Jurnal Manajemen Universitas Udayana.

Sejati, F. R., Ponto, S., Prasetianingrum, S., Sumartono, S., \& Sumbari, N. N. (2020). Faktor-Faktor Yang Mempengaruhi Kebijakan Dividen. Berkala Akuntansi Dan Keuangan Indonesia. https://doi.org/10.20473/baki.v5i2.21480

Cisilia, A., \& Amanah, L. (2017). PENGARUH PROFITABILITAS, LEVERAGE, CASH POSITION, GROWTH DAN KEPEMILIKAN MANAJERIAL TERHADAP KEBIJAKAN DIVIDEN. Jurnal IImu Dan Riset Akuntansi. 
Agustina, L., \& Andayani. (2016). Pengaruh Kinerja Keuangan, Ukuran Perusahaan, dan Pertumbuhan Perusahaan terhadap Kebijakan Dividen. Jurnal Ilmu Dan Riset Akuntansi.

Bansaleng, R., Saerang, I., \& Tommy, P. (2014). Kebijakan Hutang, Struktur Kepemilikan Dan Profitabilitas Terhadap Kebijakan Dividen Pada Perusahaan Food and Beverage Di Bursa Efek Indonesia. Jurnal Riset Ekonomi, Manajemen, Bisnis Dan Akuntansi.

Putu, N., Devi, Y., Made, N., \& Erawati, A. (2014). Pengaruh Kepemilikan Manajerial, Leverage, Dan Ukuran Perusahaan Pada Kebijakan Dividen Perusahaan Manufaktur. Jurnal Akuntansi Universitas Udayana.

Silaban, D. P., \& Purnawati, N. K. (2016). Effect of Profitability, Ownership Structure, Company Growth and Business Effectiveness on Dividend Policy in Manufacturing Companies. E-Jurnal Manajemen Unud.

Putri, A. R. (2017). Pengaruh Kebijakan Hutang, Profitabilitas, Likuiditas, dan Kesempatan Investasi terhadap Kebijakan Dividen. Jurnal IImu Dan Riset Akuntansi.

Hardi, S., \& Andestiana, R. (2018). Pengaruh Profitabilitas, Kebijakan Hutang dan Pertumbuhan Aset Terhadap Kebijakan Dividen (Pada Perusahaan Food And Beverage Yang Terdaftar Di Bursa Efek Indonesia Periode 2013-2017). Dinamika Umt.

Bursa Efek Indonesia. (n.d.). https://doi.org/www.idx.co.id 